\title{
NATIONALISM-ORIENTED INTERACTIVE MATERIALS FOR NEWS ITEMS LEARNING IN JUNIOR HIGH SCHOOL
}

\author{
Ixsir Eliya \\ Institut Agama Islam Negeri (IAIN) Bengkulu, Indonesia \\ Jalan Raden Fatah, Pagar Dewa, Bengkulu, Indonesia \\ Corresponding Author: ixsir@iainbengkulu.ac.id
}

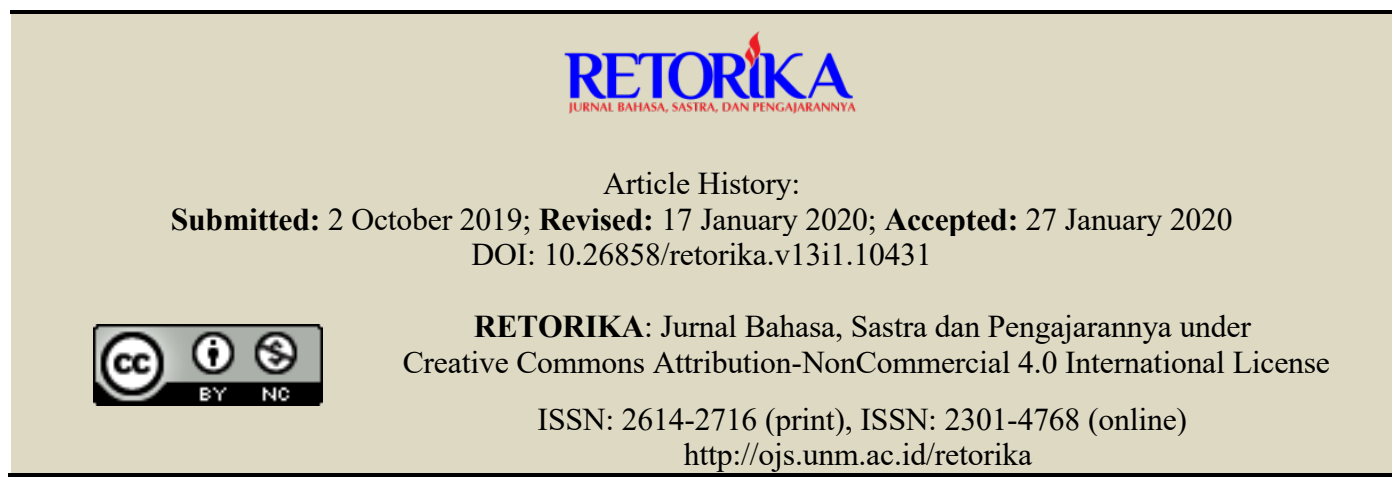

\begin{abstract}
The values of nationalism can be integrated into instructional materials as a way to achieve competence standards set by the government. This study aimed to produce nationalismoriented interactive materials for news item learning in junior high school. This study employed a research and development design that consisted of seven stages, including data analysis, product design, prototype development, expert validation, product revision, small-group tryout, and final model revision. The result of the analysis showed that the interactive materials could meet the teacher's and students' needs in learning news item and the development of the product was in line with the principle of instructional material development. The interactive instructional materials were packaged in a compact disk (CD) containing an application called Macromedia Flash. The values of nationalism integrated in the instructional materials include the pride in the national language which is Indonesian Language, the love for the country, the spirit of preserving national songs, heroism, discipline, and hard work. These values were embedded in the form of visual, audio, or audiovisual media that can be displayed in the classroom and thus used to study listening.
\end{abstract}

Keywords: instructional material(s), listening, nationalism oriented, news item

Student sense of nationalism and patriotism has been diminishing. "The nationalism of the Indonesian people has diminished because the people have been prioritizing the interests of certain groups or regions above national interests" (Soegito 2008:3). Student decreased nationalism and patriotism can be the result of the strong influence from a dominant group, weak moral compass, low sense of individual responsibility as citizens, a culture of excessive material glorification, poor knowledge of Indonesian cultural insights, and the absence of actual implementation of nationalism spirit in daily life. These phenomena confirm that education in Indonesia has not been able to form student strong national character. 
Law No. 20 of 2003 affirms that national education should be run based on Pancasila and the 1945 Constitution of the Republic of Indonesia. "The achievement of educational goals is highly determined by several factors, including the instructors, students, learning approaches, learning models, and instructional materials" (Mana, 2017). To achieve educational goals, all pedagogical activities should be appropriate, based on, and constitute an effort to implement the values conceived in Pancasila. In other words, learning activities should be designed to facilitate the development of student nationalism spirit and the formation of student national character.

The values of nationalism can be integrated into instructional materials. "It is imperative to instill nationalism values into students so that Indonesian culture can be preserved and not be overwhelmed by foreign cultures and claimed by other countries" (Nugraha, Nurhadji, and Sari, Nevanda Depika: 2017). Instructional materials are designed based on some cognitive, affective, and psychomotoric aspects that have been determined by the educational institution and the government. Instructional materials are learning tools through which students are facilitated to acquire knowledge. The teacher can help the students achieve learning objectives effectively through the use of instructional materials. Instructional materials have beneficial functions, values, and roles. Monotonous instructional materials prevent students from being inspired and motivated to grow. Teacher-centered learning activities that ignore the importance of effective, creative, and innovative instructional materials produce students who are weak in cognitive, affective, and psychomotoric domains.

The text-based Indonesian language learning in junior high schools is designed based on the 2013 curriculum. Mahsun (2014: 212) explains that "the purpose of text-based learning is to help students understand and implement texts in accordance with the social goals of the texts". This is in line with the statement that the 2013 curriculum plays a role as a defender of knowledge that helps students learn other subjects more easily. One of the texts studied by the students in junior high schools is news item texts. The purpose of studying news items in junior high school is to understand the structure and elements of news item texts based on the news that is heard or read.

Based on the results of preliminary interviews conducted with a number of Indonesian language teachers, it was found that learning to listen to news through radio or television was challenging for the students. Either the teacher or the students were more likely to face the following problems: 1) students' lack of motivation in classroom participation, 2) teacher's poor classroom management skill, and 3) inadequate appropriate instructional materials.

In fact, the Indonesian language teachers have used instructional materials to teach listening news items for the students. They utilized "Interactive Materials for Identifying News Headlines" developed by Ridwan in 2012 and "Instructional Materials for Listening to the Television News" developed by Kurniawan in 2011. The "Interactive Materials for Identifying News Headlines" were in the form of audiovisual video packaged in a CD (Compact Disc). This CD contains complete materials, practice exercises, and evaluation. However, there are several shortcomings identified in the videos, such as the monotonous design and appearance of the media and the lack of character education content. Unlike the media developed by Ridwan, the "Instructional Materials for Listening to the Television News" came in the form of audiovisual videos presented in a $C D$. The $C D$ contains a collection of videos taken from a news broadcast on one television station and there are no material and practice questions provided with it. The two instructional materials are no longer appropriate since they have not been designed based on the 2013 curriculum.

The textbook published by the Center for Bookkeeping of the Ministry of Education contains general materials of news items learning and simple texts for listening lessons. According to the textbook, the activity for listening to news items can be conducted by reading aloud a news item text to the students in front of the classroom. Then the students can be divided into groups and in the groups, one student reads aloud the text and the rest will listen to it. Sometimes, students are given homework to listen to news through radio or television and discuss it the next day in the classroom. This activity is less effective since the teacher can only see the result instead of the process of students. 
In learning to listen to news, the teacher uses simulation materials that cannot inspire the students or provide them with nationalismoriented education. In fact, during the learning process, students perform the process of thinking and reasoning. Therefore, news that contains good moral values can help students develop their character.

Student motivation and enthusiasm in learning to listen to news items can be improved through the use of interesting, inspiring, understandable, and interactive instructional materials. Research by Mitchell Kapoor shows that young people have not used their expertise in accessing digital media to obtain self-development information (Novrianti et al: 2018). Instructional materials should be designed to ease students in learning from anywhere. Therefore, instructional materials developed in this study were packaged in a software called Macromedia Flash. Macromedia flash can combine a variety of media, such as audios, visuals, texts, and interconnected videos. It also allows the user to use the keyboard or the mouse to interact directly with the materials. The interactive materials were combined in one interactive $\mathrm{CD}$.

The interactive materials developed in this study also integrated the values of nationalism. Thus, these interactive materials can also implant the spirit of nationalism in students. Jakni (2014: 261) argues that "nationalism and knowledge of archipelago function as a guide, motivation, and encouragement for state administrators at national and regional levels and all Indonesian people to establish policies, make decisions, and conduct actions".

The integration of nationalism values into the Indonesian language instructional materials is strongly needed. Through listening to news item texts, students are expected to be able to absorb and strengthen their nationalism values. Nationalism values were integrated in all of the elements that construct the instructional materials. The news used as a material for simulating questions and evaluations was an insightful news that contains nationalism issues. The components that build the instructional materials consisted of 1) the identity of the materials, including the name of the subject taught, the name of the class taught, and learning objectives, 2) instructional materials in the form of news definitions, news elements, definitions of news items, definitions of finding news headlines, steps to find news headlines, concept maps of news headlines, and considerations to identify the elements of news and headlines, 3) examples, 4) practice questions, and 5) evaluation.

Research on the development of interactive instructional materials with a national perspective for listening has been carried out by Kitao (1997) with the title "Selecting and Developing Teaching/ Learning Materials". This study suggests that learning must be conducted in accordance with the students' needs; thus, learning involves teaching methods, teaching materials, and evaluation. Instructional or teaching materials are important since teachers and students are highly dependent on them. Instructional materials should designed based on the students' needs and the applicable curriculum standards. Teachers need to find quality instructtional or teaching materials to carry out a successfull learning process.

Lavelle (2000) in his research "Getting the Most from Textbook Listening Activities" found that listening activities can benefit students in some ways. In addition to obtaining information, students can also expand knowledge about grammar, lexical, interactive, and communication through listening.

Ulumuddin (2012) in the study entitled "The Development of Instructional Materials for Teaching Religious Poetry Writing for Madrasah Aliyah students" developed an instructional material that could improve student learning outcomes and ability to write a poem. The students' learning achievement was observed through a pretest and a post-test. In the pretest, the students obtained an average score of 56.3 where $30 \%$ of them were able to complete the learning standard. However, in the post-test, the students' score improved to 93.3 where $100 \%$ of the students completed the learning standard. Damayanti (2012) in her study entitled "The Development of a Learning Medium for Listening to Folktales using Adobe Flash for the Seventh Graders" showed that the learning medium could assist the teacher and the students in the learning process.

Unlike the previous research, this study particularly aimed to develop instructional materials that contain nationalism values for news item learning in junior high school. These instructional materials were packaged in an interactive $\mathrm{CD}$ that can be used for independent learning. 
These interactive instructional materials are expected to be able to foster students' nationnalism, build students' national characters, increase students' enthusiasm and motivation in learning to listen to news items, and help teachers in the learning process. These interactive instructional materials aim to accommodate the purposes of learning that are to study theories and obtain experiences. Learning is not only limited to listening, or dictating infor-mation or theories, but also practicing the know-ledge.

This study aimed to (1) describe the teacher's and students' needs for interactive materials that can be used to learn how to listen to news items in junior high school, (2) produce nationnalism-oriented interactive instructional materials for junior high school students, (3) describe the result of the expert validation on the nationnalism-oriented interactive instructional materials, (4) use the materials to teach listening at SMP N 4 Pemalang, Mts Ikhsaniyah Banyumudal, and SMP N 1 Moga, (5) describe the participants' responses towards the product feasibility.

\section{METHOD}

A research and development design was employed in this study. As suggested by Sugiyono (2009), development research is conducted to produce a particular product and test the effectiveness. Due to time constraint, this study only adopted seven out of ten Borg and Gall's research and development steps and excluded the dissemination stage.

The seven stages included (1) needs analysis, which referred to the process of determining the needs of teachers and students for nationalism-oriented interactive instructional materials for news item listening; (2) product design, i.e. designing the product based on the result of the needs analysis; (3) prototype development that aimed to produce nationalismoriented interactive instructional materials for news item listening; (4) expert validation that was conducted by experts in interactive instructionnal materials, nationalism, and news item discourse, and teacher practitioners; (5) product revision that aimed to improve the product based on the suggestions and evaluations from the experts; (6) small-group tryout which involved the activities to test the product to a small group of students. The tryout was conducted to the eighth graders from SMPN 4 Pemalang, MTs Ihsaniyah Banyumudal, and SMPN 1 Moga. The test was performed to determine the feasibility of the product in the classroom; (7) final product revision which was conducted based on the result of the students" questionnaires and observation sheets from the small-group tryout. This was done in the form of reflective activity.

The data of this study consisted of (1) the score of the student and teacher questionnaires obtained from needs analysis, (2) reviews and suggestions from the experts and practitioners, (3) the validity score of the product, (4) relevant photos or images, (5) the small-group tryout score. The sources of the data consisted of (1) teachers and students from three schools, namely SMP N 4 Pemalang, SMP N 1 Moga, and MTs ihsaniyah Banyumudal, (2) Indonesian teachers from SMP N 4 Pemalang, SMP N 1 Moga, and MTs ihsaniyah Banyumudal, and (3) experts in interactive instructional materials, nationalism, and news item discourse.

The instruments used were non-test instruments, namely questionnaires, observation sheets, and instruments for validation and feasibility response tests. These instruments complemented each other as data triangulation. The questionnaire was used to determine the needs of the teachers and students for national-oriented interactive instructional materials for news item listening. The validation instrument was in the form of a rubric to assess the validity of the materials. The observation sheets were used to investigate interactions occurring during the implementation of the materials in the classroom. The observation was conducted by the teacher as a practitioner. The data were analyzed qualitatively (Sugiyono, 2011).

\section{RESULTS AND DISCUSSION}

\section{Results}

The results of the study were discussed under the following topics (1) the result of the needs analysis conducted to a group of teachers 
and students, (2) the profile of the nationalismoriented interactive instructional materials for news item listening, (3) the result of the expert validation on the interactive instructional materials, (4) the implementation of the materials in SMP N 4 Pemalang, Mts Ikhsaniyah Banyumudal, and SMP N 1 Moga , (5) the teacher's and students' responses towards the feasibility of the materials.

\section{The Result of the Needs Analysis}

Needs analysis was conducted to 60 students and 3 teachers from SMPN 1 Moga, SMP Negeri 4 Pemalang and MTs Ihsaniyah Banyumudal. Teacher and student questionnaires were distributed to analyze the needs of the teachers and students for material content, presentation, graphics, and language.

Firstly, the needs analysis showed that the teachers and the students agreed that interactive instructional materials should be packaged in the form of interactive CD containing material exposure, sample questions, exercises, and evaluation questions. In addition, there was also a need for instructions for use, lesson identity, and bibliography. Exposure to the material was expected to use short, clear, and communicative sentences. It was also expected that the example questions and practice questions could be designed in such a way to help students think and reason, guide, and provide coherent ways of thinking without the help of the teacher. The form of questions in the evaluation section should consist of multiple-choice questions. The materials should contain menu instructions for the use and identity of lessons so the students can study the materials more comfortably. The teacher also believed that it was important to include bibliography in the materials for justification.

The teachers and students were very excited about the integration of nationalism values into the instructional materials. Other values that can be inserted into the materials also include the pride in the national language, the love for the country, the spirit to preserve national songs, heroism, discipline, and hard work.

Secondly, the participants agreed that instructional materials should be presented in a CD since it is more usable, interesting, effective, and efficient. The values of nationalism can be actualized in all aspects, including, illustrations, music, and news presented as materials. The teachers and students also hoped for systematic and focused materials that used simple and understandable language. The teachers and the students agreed that instructional materials should be clear and unambiguous. The language used must be in accordance with the Enhanced Indonesian Spelling System (EYD). If the instructional materials are easy to understand, then the students can also easily learn the message conveyed through the materials.

Thirdly, the teachers and the students agreed that instructional materials should be presented with colorful illustrations. The students especially preferred striking to soft colors. The majority of the participants desired bigger fonts to distinguish the title and sub-title of the materials. The preferred font was Lucida Handwriting because it looks more interesting, clear, beautiful, and stylish. The size and type of letters and fonts used in these materials was adjusted to the students' needs instead of the students' wants. The students also mentioned the needs for interactive listening materials.

The teacher questionnaire revealed the important aspects needed to design instructional materials. The teachers preferred original pictures or photos with more interesting descriptions, interesting cartoons that were put on the sidelines or enclosed in the text. The illustrations, according to the teachers, would help the students understand the materials better. The teachers were more into medium size pictures instead of too big or too small illustrations. According to some of the teachers, it was even better if the size of the illustrations could meet the needs of the students. The teachers had different opinions on image colors. Some teachers chose soft colors over striking colors because according to them, it was easier for the students to see the pictures if they were presented in soft colors. For some others, striking colors can be useful because they can boost students' excitement. The preferable size of the letters in the title of teaching materials was medium. However, there was a teacher who thought that uppercase letters were more appealing. Two teachers agreed that interactive learning materials were more effective and efficient because they could provide recordings as well as supporting texts that made learning more interactive. However, there was one teacher who preferred varied audio, audiovisual, and interactive materials to attract students' attention in learning. 
The fourth need was associated with the linguistic aspects of the materials. the needs of students and teachers are based on linguistic aspects. Either the teachers or the students agreed that the use of formal language that is according to the EYD would help the students practice using the language correctly and appropriately. There was also an opinion from the teachers that suggested the use of mixed formal and informal language. The utilization of mixed formal and informal language can both enhance the students' ability to use Indonesian language and help preserve the function of the language as the national language among the students.

\section{The Profile of the Nationalism-Oriented Interactive Materials for News Item Learning}

The nationalism-oriented interactive materials for news item learning were focused on one basic competence. The materials consist of the opening, content, and closing. The opening contains the title, identity, instructions, and competence to be achived by the students.

The interactive learning materials were packaged in a CD accompanied with Macromedia Flash software. The prominent aspect of the materials was the delivery of applicable aspects of learning that cannot be found in the textbook. Besides, the materials also featured nationalism values that were integrated into the news presented. The audio and visual presentation of the materials from frame to frame also displayed the values of nationalism.

The materials were designed by considering the linguistic aspects and news aspects that support the achievement of the competence. The content consisted of instructional materials, examples of how to find news elements, practice exercises, and evaluation. The presentation of concepts, definitions, procedures, examples, and practices was adapted to the students' needs. The outline of the materials covered the cognitive, affective, and psychomotoric domains and the difficulty level of the materials was adjusted to student development.

The materials were presented interactively so that the students were encouraged to study them. The materials were also designed to improve the students' critical thinking on the news presented. The students were expected to be able to learn positive values conceived in the news. These interactive materials were also accompanied with complete bibliography to ensure the accuracy of the content.

The language used in the materials was modified according to the intellectual and emotional development of the students. It was communicative and unambiguous. The sentences used were simple sentences to ease the students' comprehension of the materials.

The graphic of the materials was designed as interesting as possible to reduce students' boredom. The layout and the cover were also designed in an appropriate way. The font used was attractive and legible. The size and the type of the font used were proportional. The illustrations were designed to boost students' interest in learning.

The development of the instructional materials consisted of designing: (1) the cover; (2) the materials, (3) examples, (4) exercises, (5) evaluation, (6) profile, and (7) bibliography. Each stage was described in detail as follows. In the beginning, animated pictures were presented as a form of love for the nation and accompanied by national music and instruments. The accompanying music was provided to attract students' attention so that the students can sincerely feel the vibe. Then, the title and identity of the materials as well as the learning objectives were presented. After that, the students were informed about the instructions of how to use the materials.

The definition, structure, and element of news as well the steps to finding the news elements were taught to the students. These interactive materials could be selected from the menu. The materials were also available in textbooks. The coverage of the materials was adjusted to the basic competence of news item listening. The content of the materials consisted of facts, concepts, principles, and procedures. The materials were presented attractively, less monotonous. The materials also integrated nationalism values so that they were useful for the students' life. The integration of nationalism values into the materials could be found in the news presented. The news discussed various topics on nationalism.

The examples found in the materials were news videos that brought up nationalism issues. These examples guided the students to determine 
the structure of the news and find the elements of the news. The examples also contained the procedures and steps to find the news elements. The examples were presented to assist the students in understanding the materials. The first worksheet described the language structure of the news item text presented, while the second worksheet contained the concept map of the news and supporting statements.

In the exercises, the students were asked to find the elements of the news. This part contained a video that can be used as an exercise before the students worked on the evaluation section about Indonesian language as an international language and attitudes against western songs to preserve nationalism. The theme of the video was love for Indonesian language. Junior high school students nowadays have been accustomed to alay language. Therefore, through this video, it was expected that the students could develop pride, love, and spirit in Indonesian language use. The format of the video was made similar to the format of the exercise of finding news elements.

The evaluation section was designed to evaluate the students' comprehension of the materials. The multiple-choice tests only appeared once; thus the students could not repeat the question twice. There are two test packages contained for evaluation: evaluation package and remedial package. Each package consists of 10 questions. There were five news presented in each package. If the students failed in the evaluation package (if they obtained scores less than $80)$.

\section{The Result of the Expert Validation o the Nationalism-Oriented Interactive Materials}

The prototype of the nationalism-oriented interactive materials was designed for validation by experts and practitioners. The results of the observation conducted in the three schools and validation of two experts and of three teachers were described in the following sections.

The first aspect evaluated was the cover and label of the CD. The result showed a score of 85.41 from the teachers and 78.13 from the experts. As a result, the cover of the materials obtained an average score of 81.77 that can be categorized into very good category.

The second aspect evaluated was the content of the materials. The aspects assessed in- cluded (1) materials, (2) visual, (3) fonts, (4) audio, and (5) the whole package of the materials. The materials obtained scores of 95.23 and 88.39 from the teachers and experts, respectively; thus the average score was 91.81. The visual achieved 91.6 and 81.25 from the teachers and the experts, respectively; thus the average score was 86.45 (very good). The font of the materials obtained 86.66 and 87.5 from the teachers and experts, respectively; hence, the average score was 87.08 (very good). The audio received 87.50 and 68.75 from from the teachers and experts, respectively; hence, the average score was 78.125 (very good). The presentation of the materials as a whole obtained a score of 87.5 from both the teachers and the experts.

Based on the explanations above, it can be concluded that the nationalism-oriented interacttive materials obtained very good scores, where they achieved scores of $81.77,91.81,86.45$, $87.08,78.13$, and 87.50 for the cover, materials, visual, font, audio, and presentation of the materials as a whole. Thus, the materials obtained an average score of 85.54 that can be categorized into good category.

\section{The Implementation of the Nationalism- Oriented Interactive Materials for News Item Listening}

The nationalism-oriented interactive materials were tried out to the eight graders from three schools, namely SMPN 1 Moga, MTs Ihsaniyah Banyumudal, and SMPN 4 Pemalang. The tryouts were conducted to investigate the students' perception and response towards the materials. The researchers and the teachers conducted the tryouts together. The researchers acted as the model teachers and the teachers observed the learning processes in the classrooms. Learning was conducted in two meetings. In the first meeting, the students were taught about the structure and principles of a news item text. The students were invited into the computer laboratory and taught how to use the interactive CD. The students at this stage showed a big enthusiasm. They paid attention to the materials and patiently wrote the explanations from the teacher. The students diligently worked on the exercises and listened to the news attentively.

The evaluation was conducted in three sections, pre, whilst, and post. The highest score achieved by the students was 91 out of 100 
(91\%). It showed that the interactive materials were effective and efficient and can be used by the students for independent learning.

The second meeting taught the students about the elements of news. The students were guided to find the elements of news from listening to the news item text presented to them. The students were asked to discover the pattern and type it directly on the media. The students were very enthusiastic because this learning experience was new for them.

After being successful in finding the elements of the news with the score of 97, the students were encouraged to work on the evaluation test that contained multiple-choice questions. The result showed that in average, the students could achieve a score of 87 in the test. This finding suggests that the interactive materials were highly feasible.

\section{Responses Towards the Use of the Nationalism- Oriented Interactive Materials for News Item Learning}

The teachers' and students' responses towards the use of the nationalism-oriented interactive materials were gathered using questionnaires. The questionnaires were distributed to 60 students and 3 Indonesian language teachers. The result of the survey showed an average score of $89 \%$ (very good). This finding indicates that the materials were plausible to use in the classrooms.

\section{Discussion}

There was no significant difference between the result of the needs analysis and expert validation. Some aspects were considered important in the needs analysis, but were less appropriate based on the expert judgement.

In the needs analysis, the teachers and the students agreed with the importance of materials exposure, examples, practices, and evaluation. The expert validation results also confirmed this opinions. Similarly, instructions, identity of the lesson, materials, examples, and practice exercises should be provided together with the instructional materials. Unlike the result of the needs analysis, the expert validation suggested a more interesting background to the evaluation.

The integration of nationalism values into the materials was nicely done. The result of the expert validation showed that the interactive materials had contained the following values: the pride in the national language which is Indonesian Language, the love for the country, the spirit of preserving national songs, heroism, discipline, and hard work.

The integration of the values had also been adjusted with the graphics of the materials. The materials taught the students how to develop pride and love for their country as well as to grow optimism and nationalism in the students. Through the videos and news presented in the materials, the students were practically introduced to Indonesian culture and the struggles of national figures for independence.

The result of the expert validation also justified the presentation of the materials as interactive $\mathrm{CD}$. According to the experts, the font, illustrations, and color should be selected based on the needs of the students, not merely based on the result of the questionnaire.

The interactive materials were able to provide effective news item learning through audiovisual materials. Nurgiyantoro (1988: 218) argues that listening skills are about to reveal the students' ability to capture and understand information contained in the discourse through listening. The listening test should be focused on appropriate discourse in audio or audiovisual forms.

Widodo and Jasmadi (2008:42) add "instructional materials should contain title, competence, objective, materials, steps, exercises, and evaluation". The materials developed in this study had met the requirements of appropriate materials suggested by the experts. "Instructional materials contain not only the training of skills but also attitudes" (Lestari, 2013:2). The attitudes are characters that should be developed in students. Students need to be skilful in both cognitive and affective domains. These instructtional materials have accommodated this purpose; they help develop the students' ability to understand the content and practice the skill of listening to news item, and also develop the sense of nationalism.

Instructional materials that were desired by the students and the teachers were interactive materials that are packaged in multimedia. "Interactive multimedia-based instructional materials provide materials with more concrete understanding" Widodo and Jasmadi (1998:52). 
Based on the explanations, it can be concluded that the instructional materials developed in this study could be used for independent learning or classroom learning. Widodo \& Jasmadi in Lestari (2013:2) state that according to the Directorate of Vocational School Teachers and Middle and Elementary Education in 2003, instructional materials possess the following characteristics: self instructional, self contained, stand alone, adaptive, and user friendly.

Self instructional materials provide the opportunity for the students to learn independently outside the classroom. The instructional materials developed in this study have been able to facilitate the students to learn independently outside the classroom by providing specific exposure of materials and clear learning objectives and basic competences that have to be attained at the end.

The nationalism-oriented interactive materials are self contained. The materials contain one competence unit or sub-competence that can be learned thoroughly in a single package. The basic competence that has to be achieved by the junior high school students was to be able to listen to news item texts. The nationalismoriented interactive materials stand alone. They are independent and thus can be used without referring to other instructional materials. By using these materials, students are allowed to achieve the predetemined learning objective.

The nationalism-oriented interactive materials are adaptive to the science and technology advancement. They were developed using Macromedia Flash that is modern, interesting, and encouraging. The students were allowed to respond and access the materials easily. Thus, the materials are also user friendly.

Based on the explanations, it can be concluded that the nationalism-oriented interactive materials have meet the requirements of appropriate instructional materials as suggested by the Directorate of Vocational School Teachers and Middle and Elementary Education. Besides, the materials should also be excellent in terms of content, presentation, graphics, and language use. Thorn in Hasrul (2010) proposes six criteria of interactive instructional media.

The first criterion is navigation simplicity. An interactive CD must be designed as simply as possible so that even non-knowledgeable users can learn from it. This criterion has been fulfilled by the interactive instructional materials developed in this study since the CD contains navigation buttons that can be used by the students to select the menu.

The second criterion is comprehensible cognition content. The materials contained in the CD developed in this study have fulfilled the standard of competence of news item listening. The materials are also accompanied with examples, practice exercises, and evaluation so that the students can practice listening to the news directly from the CD.

The third criterion is the presentation of the information. It also refers to the response of the user. These interactive materials have been tried out to 60 students to elicit their responses towards the feasibility of the materials. The result of the expert validation also showed that the materials were feasible and plausible to use in the classroom.

The fourth criterion is to examine whether the media have integrated knowledge and skills. This criterion is almost similar to the second criterion. The interactive materials developed in this study have integrated the knowledge and skills in news item listening. Besides, the values of nationalism have also been inserted to the materials.

The fifth criterion is the artistic and aesthetic aspect of the media. To attract students in learning, the program has to be presented attracttively. This criterion can be found in the materials of which presentation is appealing to the students. The images, music and font accompanying the content are all approriate and interesting.

The last criterion to be considered is the function of the media as a whole. The program developed has to be able to provide students with learning activity that suits the needs of the students. Before developing the nationalismoriented interactive materials, a needs analysis was conducted to the target students and teachers. Thus, these interactive materials have been adjusted to the needs of the students and teachers for news item learning.

The interactive instructional materials developed in this study are more effective when used by the junior high school students for independent learning. This is in line with the objecttive of Education 4.0 that is to require every individual to grow according to the advancement of technology and sciences (Eliya, 2019) 
In terms of format, the interactive instructtional materials developed in this study are more appealing than other materials because they are accompanied with sound, animated pictures, and videos. The interactive instructional materials for news item learning can also be used to provide students with the knowledge of nationalism.

These instructional materials can be used for independent learning so that students can study by themselves without any assistance from the teachers. Clear instructions have been provided on the $\mathrm{CD}$ box and inside the $\mathrm{CD}$ so that the students can easily operate the program. The students can also interact directly with the texts, materials, examples, and practice exercises provided in the $\mathrm{CD}$. In addition, the students can also test their comprehension by doing the evaluation test. The animated pictures and songs accompanying the materials may engage the students in active learning.

The nationalism-oriented interactive materials have some benefits that characterize the materials. The unique characteristics of the materials that make them different from other audiovisual materials are: (1) the materials ease the process of listening to news items because they are packaged in an effective and interesting form for students; (2) the evaluation section found in the CD guides the students to listen attentively to news item texts and there are a remedial package and practice exercises provided for the students; (3) the interactive materials integrate nationalism values so that the students can learn to develop the sense of pride in their country; (4) the news presented in the materials indirectly grows nationalism.

\section{CONCLUSION}

The nationalism-oriented interactive materials developed in this study are packaged in a

\section{REFERENCES}

Ulumuddin, A. (2012). Pengembangan bahan ajar menulis puisi berkonteks lingkungan peserta didik bermuatan nilai-Nilai religius untuk Madrasah Aliyah. Thesis. Semarang: Universitas Negeri Semarang.

Damayanti, K. L. (2012). Pengembangan media pembelajaran menyimak dongeng dengan program Adobe Flash bagi siswa SMP Kelas VII.
CD containing Macromedia Flash software. The prominent aspect of the $\mathrm{CD}$ was its interactive and implementative content. Besides, the materials also integrate nationalism values into each element of the news presented. The visual and audio of the news presented from frame to frame also reflects the values of nationalism.

The development of the materials also considered linguistics aspects and elements of news so that the materials can help the students achieve the basic competence. The CD contains instructional materials, examples of how to find elements of news, practice exercises, and evaluation tests. The concept, definition, principle, procedure, examples, and practice exercises for news item listening are presented based on the students' needs. The materials are designed based on the students' development stage in cognitive, affective, and psychomotoric domains.

The nationalism-oriented interactive materials have been designed based on the needs of the students and the teachers for news item learning. Based on the results of the study, it is recommended for Indonesian language teachers to use these interactive instructional materials because these materials can improve students' active participation in learning, creativity, and create a fun learning atmosphere for the students to listen to news items appropriately.

Through the nationalism-oriented interactive materials, it is expected that the students can be inspired to be nationalist and to be able to apply nationalist characters in their daily life. It is strongly suggested to conduct further research to investigate the effectiveness of the the nationalism-oriented interactive materials in improving students' skills in listening to news items. It is expected that the results of future studies can provide an insight to the refinement of the product developed in the current study.

Thesis. Semarang: Universitas Negeri Semarang.

Djuraid, H. N. (2006). Panduan menulis berita. Malang: UMM Press.

Eliya, I. A. S. (2019). Penguatan keilmuan mahasiswa melalui gerakan sadar literasi dalam upaya menangkal radikalisme dan berita hoaks di media sosial. International Seminar on Islamic 
Studies, IAIN Bengkulu, March 28 2019, p.p. 63-269.

Hasrul. (2010). Langkah-langkah pengembangan pembelajaran multimedia interaktif. Jurnal Medtek, 2(1): 1-8

Jakni. (2014). Pendidikan kewarganegaraan di Perguruan Tinggi. Bandung: Alfabeta.

Kitao, K. (1997). Selecting and developing teaching learning materials. The Internet TESL Journal, 4(4): $20-45$

Lavelle. (2000). Getting the most from textbook listening activities. The Internet TESL Journal, 6(11): 12-17

Lestari, I. (2013). Pengembangan bahan ajar berbasis kompetensi. Padang: Akademia.

Mahsun. (2014). Teks dalam pembelajaran bahasa Indonesia Kurikulum 2013. Jakarta: Raja Grafindo Persada.

Mana, L. (2017). Pengembangan RPKPS dan SAP menyimak berbasis pendekatan contekstual teaching and learning (CTL). Jurnal Gramatika: Jurnal Penelitian Pendidikan Bahasa dan Sastra Indonesia, 2(2), 84-100, https:// doi.org/10.22202/jg.2016.v2i2.986

Muslich, M. (2010). Text Book Writing. Jogjakarta: Ar-ruz Media.

Novrianti, H., Nofri, Ulfia, R. (2018). E-Modul computer based learning sebagai e-resource digital literacy bagi mahasiswa. Jurnal Educative: Journal of Educational Studies, 3(1): 58-71

Nugraha, N. \& Sari, N. D. (2017). Peran guru dalam upaya pembentukan wawasan kebangsaan pada siswa selas VIII SMPN 1 Barat Kabupaten Magetan tahun ajaran 2015/2016. Citizenship Jurnal Pendidikan Pancasila dan Kewarganegaraan, 5(1): 13-23.

Nurgiyantoro, B. (2002). Teori pengkajian fiksi. Yogyakarta: Gadjah Mada. University Press.

Prastowo, Andi. (2011). Panduan kreatif membuat bahan ajar inovatif. Jogjakarta: Diva Press.

Putu, S. W. (2012). Kewaspadaan nasional dalam mencegah disentegrasi bangsa. Jakarta: Pensil.

Soegito, A.T., et al. (2008). Pendidikan pancasila. Semarang: UPT MKU UNNES.

Sugiyono. 2009. Metode penelitian kuantitatif, kualitatif, dan R\&D. Bandung: Alfabeta.

Sulandari, N. Suwignyo, H., Hasanah, M. (2017). Pengembangan bahan ajar interaktif membaca teks dongeng untuk siswa sekolah dasar. Jurnal Pendidikan: Teori, Penelitian, dan Pengembangan, 2(8) 1132-1140

Widodo, C. S. \& Jasmadi. (2008). Panduan menyusun bahan ajar berbasis kompetensi. Jakarta: PT Elex Media Kompetindo. 